\title{
Contested meanings, myths and hyperimages of the apocalypse: the Bakhtin Circle and the politicisation of catastrophism
}

\begin{abstract}
This article considers the depoliticising effects of current images and myths of apocalyptic visions, such that the world faces a catastrophe whether this emerges from environmental degradation, mass migration, terrorism, or global financial collapse. In our digital media age, apocalyptic images are now also captured through the raw footage of actual disaster events. In the article we call such footage, 'hyperimages'. The power of the hyperimage is not, as Baudrillard once said, that reality is 'just like the movies', rather, hyperimages demonstrate that the image captured and shown to others is all too real because they depict actual everyday disasters. Importantly, such is the power of hyperimages that they are often employed by the political right to help them construct a hegemonic project aiming to win state power and to influence state policies. Drawing on the Bakhtin Circle, however, we show that hyperimages are also mediated and circulated through a multitude of social groups and voices in society, which contain seeds of radical heteroglossic alternatives to that of the right. Following this, the paper then examines how responses to apocalyptic hyperimages can be politicised in a progressive direction.
\end{abstract}

\section{KEYWORDS}

Apocalypse; Bakhtin Circle; digital media; hyperimage; myths; the state

\section{Author Bios:}

John Michael Roberts is currently based in the Department of Social Sciences, Media and Communications at Brunel University. His latest books are New Media and Public Activism (Policy Press 2014) and Digital Publics (Routledge 2014).

Colin Cremin is currently based in the Department of Sociology at Auckland University. His latest book is Totalled: Salvaging the Future from the Wreckage of Capitalism (Pluto Press 2015). 


\section{Introduction}

Whether it is the arms race or orders given to start a war that is itself dominated by that economy of speed throughout all the zones of its technology, a gap of a few seconds may decide, irreversibly, the fate of what is still now and then called humanity - plus the fate of a few other species.

Jacques Derrida (1984: 22-31)

The decade of the '00s was punctuated with political crises and images of humanengendered disaster in prosperous, developed countries: 9/11, the aftermath of Hurricane Katrina, the global financial crisis, Fukushima and the Occupy Movement. Doom is prophesised not only by the usual cranks and cults, but also by blockbuster spectacles, ecological scientists, and in a more nuanced way by economists and hirsute Marxist theorists (Dixon 2003; George 2010; Žižek 2010). As the UN Secretary General Ban Ki-moon in September 2014 said, the 'world is living in an era of unprecedented level of crises' (Borger 2014). In one respect 'crises' are all too real. Reality is nonetheless mediated and not least by how the mind interprets what is an 'apocalyptic age', or what others similarly call 'an age of catastrophism'. Encapsulating both the left and right, those who say we live in apocalyptic and catastrophic times tend to believe we exist in a state of collapse and disorder shaped by the likes of economic crises, political upheavals, environmental degradation, terrorist threats, and so on. Such turmoil will eventually give rise to a new society, but 
first people need to stir from their slumber to see the calamity that surrounds them (Lilley 2012, 1). ${ }^{1}$

Of course, today our political apocalyptic imaginary is informed and formulated by words, Hollywood spectacle and actual footage of disasters that those in the midst of them capture on their mobile devices and upload onto YouTube. Whether the image is generated by CGI or is reality captured, seen through a screen fiction and reality become interchangeable and in degrees mythologised. Nonetheless, the images we have in mind are all too real in that what they represent can literally escape the frame and consume, even kill, the viewer. Consider, for example, a person recording an approaching tsunami on their mobile phone. The screen they see the image through presents the same image that someone watching the unfolding catastrophe will see on YouTube (assuming it is uploaded onto it). For the taker, however, the image can literally escape the frame and kill them. The viewer watching the scene at a distance on their computer monitor is not in imminent danger, such images nonetheless also threaten ultimately also to escape the frame. They are signifiers of an empirically verifiable reality that, within a 'genre' of apocalyptic images from actual footage of tsunamis through to Hollywood spectacle, forewarn of catastrophes that will sooner or later consume us if we are passive to what is represented by them. The crucial issue is how these images are translated. What, in other words, do we 'make' of them and how does this impact, if at all, on our politics. In this article we wish to interrogate how material reality is mediated through

\footnotetext{
1 To give one illustration, there are the obscurantist fantasies about a 'coming apocalypse' that would end all divisions, and possibly end human life, which is seen as a cancer on nature, or lead to a pastoral future without modern industry. Derrick Jensen (2006), for instance, suggests that global warming will serendipitously bring about the collapse of industrial civilization and reduce global population to 10 per cent of its current size.
} 
ideological interpretation, distortion and myth. We aim to disentangle myth from reality while also - and this is the political task - exploring the utopian kernel of the ineluctable symbolic renderings of our 'end times'.

To begin to critically and theoretically explore these apocalyptical images our paper starts by looking at the relationship between ideological myth and reality, primarily because many apocalyptic images also endeavour to create a myth about a society's past, its present and its future. In this respect, we first discuss some perspectives on myths, which argue that myths produce ideological narratives in society on behalf of dominant groups. Roland Barthes is arguably the most wellknown proponent of this position. For all of their brilliant insights, however, these perspectives nevertheless tend to have negative views of myths, seeing them as tools for the dominant to maintain hegemony over the mases. These initial critical observations enable us to move to an alternative theory of myth as found in the work of the Bakhtin Circle. Language for the Bakhtin Circle is rendered dead or monoglossic when refracted through the prism of a dominant ideology, but rendered alive when subjected to the heteroglossia of competing 'accents'. Language is contextual, textual, intertextual and historically mediated at different levels of abstraction. Language cannot be understood without consideration of the historical context in which utterances are made and received, along with the different histories of interlocutors. Dialogue does not happen in a void (Bakhtin 1981, 291). Similarly, for the Bakhtin Circle, myths can be monologic or heteroglossic; myths both help to articulate dominant ideals and provide spaces for people to use myths to assert their own everyday images against dominant ones.

It is through this materialist and dialectical approach that we subject current 'end-of-the-world' images to a critical intelligibility. We examine how crises are 
themselves often mythologised in the apocalyptic accounts of our age. In particular, movements of the right articulate their own specific tales of catastrophism within society in order to capture and then mobilise state hegemony and power for their own political and social ends. This starting point enables us to ground an analysis of how a mass franchised and disseminated apocalyptic spectacle is reproduced through the optics of what we shall refer here to as the hyperimage (cf. Cremin 2015). This involves an examination of the homologies between cinematic and TV spectacle and the spectacular instances of real life disaster, catastrophe and so forth captured by witnesses on the scene using mobile technologies, disseminated and downloaded in montage through social media. As the Soviet documentary film-maker Dziga Vertov's kino-eye manifesto stated, some 80 or so years before the cine-camera was integrated into pocket size mass produced commodities, the power of film-making becomes more prominent when it lies in the hands of ordinary people who make images concrete. This is now realised with the hyperimage and the concretisation of spectacle, as if the spectacle itself is the doppelganger in a frame one thought a mirror that crosses the glass threshold and, as it were, punches the spectator in the face.

We then consider how material events and processes that signal or forewarn of the empirical possibility of universal catastrophe captured by those on the scene of terrorist attacks, tsunamis and so forth, are depoliticised by the unified monologic accent of a catastrophic narrative, as witness in entertainment media and the state. The problem, in other words, is not that these images, whether of actual events of fictionalised apocalyptic and dystopian scenarios commonplace in spaces such as Hollywood cinema, are 'pure fantasy', or images layered upon other images, the 'hyperreal' as Baudrillard calls it, but rather that their truth substance is depoliticised. That is to say, the futures they depict are already determined by an incapacity to 
counter them through actions that anticipate alternative scenarios. We argue that one way in which monologic apocalyptic images attempt to gain hegemony is through state power. As a materialist approach to makes clear, and as we argue throughout the article, the struggle for determination of the image is therefore not something that happens 'merely' in the sphere of culture. It is by necessity as struggle on the terrain of state power. We then make some concluding observations.

\section{Myths as dialogic forms}

Famously, Roland Barthes (2009) argued that myths are ways of naturalising events in the world. Myths transform the flow and contested quality of history into frozen time. Myths act as if they create concepts to represent the flow of history, rather than, as is the case, history creating concepts. As such, myths present a particular ideological viewpoint as being impartial and common sense, which is a way of stemming the tide of debate. As a 'metalanguage', myths conceal how ideological viewpoints are constructed by presenting us with a distorted image of a particular aspect of the world. A mythical image, for example, will claim that an object holds a specific essence, a truth perhaps, which it actually lacks. According to Mosco, therefore, 'myths are stories that animate individuals and societies by providing paths to transcendence that lift people out of the banality of everyday life. They offer an entrance to another reality, a reality once characterized by the promise of the sublime' (Mosco 2004, 3). Myths are not falsehoods as such, but provide a way for people to overcome certain contradictions they face in their daily lives. In this respect, myths help us to manage these contradictions by reinterpreting them through cultural 
objects, jokes, music, narratives, stories, and so on. 'In this respect, myths transform the messy complexities of history into the pristine gloss of nature’ (Mosco 2004, 30) and present solutions that help to make existing social contradictions seem natural.

According to Samuel and Thompson (1990), such views about myths lack a certain analytical purchase on how everyday life actually operates. They argue that instead of seeing myths as perpetuating ideological viewpoints which naturalise certain contradictions, it is of equal importance to ascertain how myths offer up points of resistance to dominant ideologies. Myths can always be employed by ordinary people at new events in order to combat dominant beliefs. Portelli (1990) gives a case in point. When interviewing an old Italian communist about his past political activities, Portelli discovered that the elderly man attributed an old popular saying 'when the thrush flies by, then is the time to shoot it' - to Lenin. For Portelli, the old man used this myth to imagine what might have occurred if certain historical events had not taken place in the Italian Communist Party, which had led it to move away from Leninism and then to eventually be defeated at successive elections. The myth gave the old man hope through an alternative discourse to the one then prevalent in the Communist Party leadership. As such, a 'myth may...take us closer to past meanings and certainly to subjectivity than...the painstaking accumulation of fact' (Samuel and Thompson 1990, 13). Myths are thus more fluid than Barthes's or Mosco's description of them.

From the discussion so far, it seems to be the case some see myth as a useful analytical tool with which to discuss ideology, while others criticise this perspective for not appreciating how myths can be used to analyse ideology. One fruitful avenue through which to reconcile these two contrasting perspectives is by means of the work of the Bakhtin Circle. Indeed, Bakhtin discusses the use of myths in relation to 
everyday language. He does this, first, by criticising the ideological use to which myths are employed. He says that mythical images bond with a 'feeling' evident in specific forms and stylistic combinations of language, and when this occurs a myth 'substitutes itself for the connections and interrelationships of reality itself' (Bakhtin 1981, 369). In this instance, myths 'fetter' the images found in everyday life by stifling the 'wider application' and 'greater flexibility' that these images might otherwise have in everyday life. As a result, myths 'limit the word's potential for greater expressiveness' (Bakhtin 1981, 369). For example, myths often place time in an 'eternal contemporaneity' that create discursive genres without any real sense of renewal, where one might live in the present but do so by always referring back to a mythical past where one’s identity is thought to be rooted in (Bakhtin 1984, 105-106). This is a monologic perspective on the world that aims to impart a unified meaning upon the lived experience of subordinate groups (Bakhtin 1981, 270; Bakhtin and Medvedev 1991, 159).

Yet, while Bakhtin appears to outline a theory of myths that is comparable to Barthes and others of a similar persuasion, he also recognises the dialogic nature of myths. For Bakhtin, society is comprised of contradictions that people face in their daily lives, and these contradictions give rise to 'heteroglossic' speech diversity in daily encounters. Heteroglossia thereby gives expression to the popular culture and experiences of centrifugal forces in society. And it is this heteroglossic potential which, according to Bakhtin, can help to 'de-centre' myths. This occurs when heteroglossia makes a myth lose its sealed-off and self-sufficient character, when a myth 'becomes conscious of itself as only one among other cultures and languages' (Bakhtin 1981, 370). At this point, heteroglossia starts to seep into the monologic form of a myth to reveal the dialogic nature of its mythical tendencies. Unitary 
meaning begins to decay, while the decentred language of heteroglossia starts to express the contradictions of life in the public sphere, finding support for these views in the once mythical unitary language of monologic discourse (Bakhtin 1981, 147). For Bakhtin, then, myths are not merely ideological but also reveal an alternative to dominant ideologies, which is the heteroglossic potential to reveal an alternative future to a monologic present defined by a static past. In the next sections, we apply these Bakhtinian insights to dialogue in and around apocalyptic discourse.

\section{Mythical crises of the apocalypse}

Apocalypses have their material provenance in crises but are not mutually exclusive (cf. Boyer 1992, 23). Reality precedes prophecy, and prophesy authors the future. Apocalyptic prophecies can be comforting - if they tell of apocalypse befalling one's enemies. Apocalypses prophesied in the Bible offered hope to the persecuted: 'great hailstones, fire and brimstone' awaited the Babylonian invaders holding siege to and sacking the city of Jerusalem (The Book of Ezekiel). Plagues, sores, great whores and a blood-drenched moon were in store for the Roman Imperial System in The Revelation of John, written during the reign of Emperor Domitian in 81-86AD. Beliefs in the apocalypse are therefore found in many cultures throughout history. As we argue below, what is unique about our times is that numerous individuals who, through the likes of social media, can project these images around the world frame apocalyptic images. In this sense, we have become spectators at a crucial historical juncture. The question we thus pose is whether the apocalyptic imaginary can be 
politicised, especially when apocalyptic speculation is typically but not exclusively produced by the mass entertainment industry.

To gain some answers, let us start with Evan Calder Williams’s observation that an apocalypse can be distinguished from crisis, the former revelatory and redemptive. In contrast, crises, says Williams, are circular in nature, restoring a former state (Williams 2011). Unlike Williams, and following Bakhtin, we see crises and apocalypses as often being entwined with one another. During a crisis, a myth is able to (mis)represent the past cause of crisis. Crises operating in particular spaces are captured by myths, which then support ideological monologic apocalyptic images. Another way of thinking of apocalypses in this respect is through Bakhtin's idea that crises often occur in thresholds between points. In everyday life, notes Bakhtin, people go through routine and expected occurrences, which happen in local spacetime contexts. In the home, one experiences everyday life at certain 'points' - a stairway, a foyer, a landing. Often, these 'points' go unnoticed (Bakhtin 1984, 169). However, 'points' can suddenly be transformed into 'crisis-time', which pushes everyday 'points' of life out of joint. What was once ordinary becomes a moment for a new awareness and a change of fate, a place where time reaches crisis-proportions and where 'everything is taken to its extreme’ (Bakhtin 1984, 167).

A crisis is thereby revelatory under Bakhtin's understanding and, importantly, a moment to devise new words and signs to make sense of it. But these do not necessarily result in heteroglossic subversion. They can also be refracted through monologic agendas, particularly through myths. After all, myths have the potential to invert the flow of time. Present and past in myths tend to have more importance over the future so that 'everything affirmative, ideal, obligatory, desired has been shifted, via the inversion, into the past' (Bakhtin 1981). These myths are monologic insofar 
that they design a past to herald an invented, eternal Golden Age as being superior to alternatives in the present and future possibilities. They thereby construct mythical revelatory themes to regulate present and future beliefs and behaviour (Bakhtin 1981, 148). Myths are thus similar to what the social historian Eric Hobsbawm terms, 'invented traditions', which aim to inculcate 'certain values and norms of behaviour by repetition which automatically implies continuity with the past' (Hobsbawn 1983, 1). Tradition must build a number of rituals that at least appear to have been handed down through generations since time immemorial, such as the wigs and robes worn by judges in a court of law (Hobsbawn 1983).

So, while it is true to say, as Benjamin Noys $(2012,13)$ notes, that crises, in our present day, are 'revelatory of the ontology of capital', it is equally true to say these revelations happen against the grain of newly created monologic mythical utterances that do not necessarily produce the circumstances for genuine critical dialogue about the nature of global capitalism. Neoliberal states, for example, have used doomsday scenarios about the 2008 global financial crisis as an opportunity to continue to generate and sustain a further set of myths about welfare scroungers in new areas of society, in new social thresholds, even in unexpected ones. Drawing on the British Attitudes Survey, the Joseph Rowntree Foundation underlines the extent to which neoliberal ideology has imparted a unified meaning to the current crisis in different thresholds of society. There is a 'general trend', they claim, of blaming the individual rather than society for poverty. In 1986, 41 per cent of Labour supporters attributed poverty to social injustice. By 2010, almost two years after the global financial crisis, just 27 per cent of Labour voters cite social injustice as the main cause (NatCen Social Research 2013). As reported in the Guardian, in 2011, 31 per cent of Labour supporters claimed welfare recipients were 'undeserving', higher than 
in 1987 when at the height of Thatcherism 21 per cent agreed with this statement (Ramesh 2013). Under these circumstances, thresholds of crisis align themselves with certain myths, in the above case a myth of the undeserving poor leeching off the welfare state, which can soon result in reproducing wider apocalyptic myths, such as those related to doomsday scenarios about immigrants scrambling to get the 'best' jobs in 'our' country. Importantly, these apocalyptic myths are employed by forces of the political right to articulate their own 'solutions' to these constructed 'worsening conditions', which are then used to strengthen neoliberal state power. As Davis perceptively notes in respect to the USA:

By intensifying paranoia and division about immigrants, welfare, external and internal security threats, fiscal crises, morality, and minorities, the organized right works to generate a climate in which the state can 'react' to various supposed crises... Border security is just one example where agitation from the right has contributed to the state's militarization of the US-Mexico border, and the growth of a massive internal security apparatus (Davis 2012: 79).

We will return later on in the article to the relationship between the apocalypse and the state. Before we do so, however, we need first to develop some theoretical points in order to analyse how apocalyptic myths assume specific forms in our information age. After all, monological myths profit these days from what Paul Virilio (2005) calls the 'information bomb', a fallout from the white noise of information overload via our digital age. In this context, images become a means to further apocalyptic myths and for them to gain intelligibility in society. At the same time, and as we argue below, digital culture has the potential to turn these myths into what we term are 'hyperimages'. These are images in which reality seeps through 
media forms to threaten us, but which also have the potential to show us alternative realities to those articulated by the powerful in society. Hyperimages are thus different to the hyperreal. The latter represents the hegemony of images, whereas hyperimages, in a Bakhtinian sense, provide an insight into a plethora of symbolic, heteroglossic accents. Metaphorically speaking, the hyperreal society, immobilised, observes through media forms the tsunami that fast approaches, despite the fact a 'solution' does indeed lie in escape up the nearby hill, whereas some, but not all, hyperimages can point us towards the path up the hill. Critical theory must seek, then, to overcome such depoliticised hyperreal images in order to bring the political back into a dialogic space. We now begin to address this issue.

\section{Mythical apocalyptic hyperimages}

According to Voloshinov $(1973,23)$, units of ideological meaning, or signs, that are 'withdrawn from the pressures of the social struggle...inevitably lose...force, degenerating into allegory and becoming the object not of live social intelligibility but of philological comprehension'. These signs evade contact with heteroglossic culture and instead become monologic words. Words such as 'crisis', 'catastrophe', 'end times' and 'apocalypse' are often illustrations of monologic signs in this respect to the

extent that they become withdrawn from the pressures of social struggle. The apocalyptic sign, for example, becomes a sterile one when it is given an eternal identity through the banal statement that every age is an apocalyptic one. We need, then, to bring such signs to life, subjecting them to 'live intelligibility' and in so doing think the possibility of different futures to that forewarned by ecological scientists and 
made entertainment by the culture industry. We need, in other words, to overcome what Fredric Jameson $(2012,105)$ notes is an 'incapacity to integrate a future of time into our own analysis of current society', which 'accounts for the tendency of bourgeois thought to alternate between images of regression or dystopian collapse, and conceptions of progress which amount to little more than the perfecting of what is there already'.

Bakhtin's further distinction between symbol and image is instructive in this respect. He says that a symbol is a unit of semiotic meaning that connotes the world in some way or another. As the world has indefinite meanings, a symbol likewise has indefinite contextual meanings as it becomes refracted into an array of heteroglossic themes. This is because belief systems gain ideological potency by being realised in a plethora of 'words, actions, clothing, manners, and organisations of people and things - in a word: in some definite semiotic material' (Bakhtin and Medvedev 1991, 7). Symbols thus enjoy endless material references and produce awareness in people about the world that, up until that point, they did not possess. By way of contrast, images are limited in scope, and demand merely understanding of 'significance in the given context' (Bakhtin 1986, 160) in which they have been created. That is to say, images have yet to stimulate endless contextual meaning and therefore lack true dialogic potentiality.

In terms of the apocalypse, the distinction between the symbolic and image is useful in developing an interesting take on how myths around crises, disasters, traumas and catastrophes, which come to be refracted in entertainment media, on YouTube clips and through media images on climate change, capitalism and so forth, are analysed by critical thinkers. Focus momentarily on how Baudrillard describes a 
particular apocalyptic event. Writing on the 9/11 attacks, Baudrillard described the ambiguous nature of real-life footage:

The role of images is highly ambiguous. For they capture the event (take it as hostage) at the same time as they glorify it. They can be infinitely multiplied, and at the same time act as a diversion and a neutralization (as happened for the events of May 68). One always forgets that when one speaks of the 'danger' of the media. The image consumes the event, that is, it absorbs the latter and gives it back as consumer goods. Certainly the image gives to the event an unprecedented impact, but as an image-event (Baudrillard 2003, 27; see also Baudrillard 2010).

For Baudrillard, such images have become immersed in the hyperreal. Here, the hyperreal denotes a flattened reality indistinguishable from the image that represents it. It is, he says, the 'real' which 'is not only that which can be reproduced, but that which is always already reproduced: the hyperreal' (Baudrillard 1993, 73).

When Baudrillard provocatively stated that the first Gulf War during 19901991 had not taken place, what he was referring to of course was the way war is now filtered and relayed through images drained of reference to bloodshed akin to videogames where the eye sees from the perspective of the missile and is shut at the point of impact. Actual violence and destruction was something that occurred to other people in another place, although, as Baudrillard correctly pointed out, it was hardly a war when ground troops were largely absent and the adversaries so imbalanced. In this instance, then, the image-event fashions reality. More broadly, Baudrillard says that our digital age provides the context for hyperreality to thrive. Life becomes coded 
through 0 s and 1s and the constant modelling of human and social reality through digital technology (Baudrillard 1993, 58).

In terms of disasters, much has already written about how popular culture provided the fantasy frame for the 9/11 event, the most uncanny of which was an episode of the X-File spin-off The Lone Gunman, broadcast in early 2001, where terrorists having taken possession of a passenger jet liner attempted to steer it into the World Trade Center (see also Žižek 2002). Such subterranean fantasies and forebodings are realised by the singular sublime moments they foreshadow. The 9/11 event was filmed by many of the people contingently there at the scene and many were posted online. Their clips were subsequently put together in a real time sequence for the made-for-television documentary 102 Minutes that Changed America. Closeups of faces contorted by the trauma were interspersed with images of the towers billowing smoke and harrowing close-ups of people hanging from the windows. Panning shots of office workers and tourists running from the scene, policemen guiding them towards safety past shops and via commercial thoroughfares, evoked Baudrillard's hyperreal. Indeed, it is as if by situating oneself behind a lens reality is drained of its authenticity thereby restoring the hyperreal in which the taker of the shot is no longer a correspondent but only an observer. We escape reality by fictionalising it and also make it more real than real - a hyperreal - in the camera obscura of a Hollywood imaginary.

There is a sense, though, in which Baudrillard's albeit fascinating insights into hyperreality only take us so far in deciphering images of the apocalypse. The problem with Baudrillard's analysis is he thinks that reality has become a 'game' in which 'reality' is now simulated through codes. Ultimately, then, Baudillard stays at the level of the image, or its near equivalence in the dominance of signs, such as 'the sign 
of behaviour models inscribed everywhere in the media or in the layout of the city' (Baudrillard 1993, 78). In Bakhtinian terms, this is a monologic theory of the sign because it suggests 'social control by means of prediction, simulation, programmed anticipation and inderminate mutation' governs social life (Baudrillard 199, 60). This form of social control obliterates 'internal contradictions' through its ability to code and control social life (Baudrillard 1993, 60), and it thereby denies the heteroglossic potential of other signs and 'accents' to open new thresholds to critique hyperreal images. To regain a more nuanced critical analysis we therefore need to move beyond Baudrillard's overreliance on a monologic theory of the sign and image. Again, in more Bakhtinian language, we need to explore how images are not only monologic, but are also integrally related to the symbolic and its refractions of internal contradictions in society (see Harvey 2014 for good discussion of some internal contradictions of capitalism).

Susan Buck-Morss' idea is useful in thinking how the symbolic can emerge through the image. She notes that when relayed through global media, for example, an image acquires the form akin to what Susan Buck-Morss calls the inverse simulacrum.

If there is a simulation produced by television, it lies on the other side of the apparatus. It is the simulated 'whole world' that watches, the virtual collective assembled in cyberspace, of which viewers, sharing the same televisual experience, imagine themselves to be a part (Buck-Morss 2002, 254).

Here, Buck-Morss provides a basis to begin to think about what we term as 'the hyperimage'. The hyperimage relies on both technology and the body of its wielder, that is, the participant/producer whose immediate presence concretises the desired universal audience, and the portal through which the rest of that audience is deemed 
to view the action. While Atlas carried the world on his back, citizen correspondents carry an (observing) world in their hands in the form of camera phones. Everyone makes images for everyone. As Deleuze $(1986,83)$ writes: 'from the point of view of the human eye, montage is undoubtedly a construction, from the point of view of another eye, it ceases to be one; it is pure vision of a non-human eye, of an eye which would be in things.'

In this respect, the hyperimage differs from the hyperreal in a number of key respects. The first point to make here is that we are so accustomed to hyperreality that when confronted by real images of events and processes that do threaten to consume us they appear as if fictionally rendered. The meaning of the image of the first Gulf War from the perspective of the camera mounted on a missile differs according to where it is viewed. As it poses no immediate or long-term threat, the image from the perspective of those watching it in the United States is indeed hyperreal. It is as if by framing it as a movie, the event ceases to be real or something perhaps imagined to be seen through the eyes of someone viewing it on YouTube in the safety of their home. The hyperreal in such respects functions as the mystification of reality. Irrespective of whether they identify the image as real or fiction, if somebody living in Bagdad now views the same image it will obviously have a different impact. The image poses either an immediate or an indirect threat to the person watching it and therefore it escapes being hyperreal and instead becomes a hyperimage. In other words, when what is depicted literally threatens (rather than an imagined threat) the territories hitherto unaffected by such events, that we are in the era of the hyperimage proper.

The hyperimage is therefore an image that can potentially, or actually, escape its frame. In the early 1980s at the high point of the Cold War, The Day After and Threads, produced for US and UK television audiences respectively, depicted the 
effect of a nuclear war on urban populations (Kansas in the US and Sheffield in the UK). The latter in particular was a highly plausible and, for this reason, an incredibly disturbing account of what it would be like to live in the aftermath of a nuclear war. Threads is a rare example of a film whose depiction of an apocalyptic scenario in a major centre of cultural production is so realistic and historically plausible that it can be considered a hyperimage. The less realistic, the less plausible and the more distant in time and or space, the more hyperreal the depiction is. As a result, the hyperimage is reality that must, to be rendered neutral, be 'hyperrealised'.

So, when disasters, traumas and catastrophes are relayed by observers using mobile devices and posted on YouTube, the images acquire a higher degree of authenticity that, when as spectacular as cinema, produces an uncanny effect. The miniaturisation of camera technologies embedded in mobile phones and typically at hand, along with Internet tools that enable the dissemination of raw footage without necessary reliance on the curation of traditional media industries, has given rise to a phenomenon that the early Soviet documentary filmmaker Dziga Vertov anticipated in his Kino-Eye manifesto. The aim of Kino-Eye was, according to Vertov, to 'create an army of cine-observers and cine-correspondents (to move) away from the authorship of a single person to mass authorship, with the aim of organising a montage vision - not an accidental but a necessary and sufficient overview of the world every few hours’ (cf. Milne et al., 2012, 105). The dream has only now been realised. The world sees through the collective eye of millions of cine-correspondents. Hyperlinks and clips linked together by complex algorithms enable the cine-observer to organise their own montage vision of apocalyptic texts (although the options offered most prominently to them are not without mediation). Reality plays out 'just 
like the movies' but, more to the point, reality is a movie, ideology objectified in montage by a common eye.

It is at this point that we return to Bakhtin's distinction between image and the symbolic. For, if everyone is indeed making images for everyone else, then an interesting possibility arises. Rather than the monoglossia of single-voiced images, we can begin to appreciate multi-voiced hyperimages for heteroglossic symbols to emerge in the cracks of the hyperreal. Today, these symbolic materials are refracted through digital culture and other everyday social and cultural forms. Not only are there images that are projections of disasters, these are now symbolised through unique 'accents' employing a plethora of technology and social forms that enact the social beyond mere images. These symbolic forms are not necessarily 'hostile to the mythic, and frequently utilises its language' (Bakhtin 1986, 169), but do so in different ways to test the limits of the hyperreal. As a result, the 'thinglike environment' constructed through monologic myths and the hyperreal are slowly impregnated by the 'accents' and 'personality' of others so that the 'potential word and tone' of a people's history are revealed, which goes against monologic myths (Bakhtin 1986, 164). The Arab Spring, for example, captured to a large degree by amateur filmmakers and posted up on social media sites, shattered the monologic apocalyptic myth constructed by western politicians and mainstream media outlets that the Muslim world was a homogeneous mass comprised by dangerous elements who wished to end western civilisation.

A dominant monologic force aiming for hegemony must therefore regulate such creative heteroglossic symbols. In the terms already spoken about, this would be a monologic power seeking to drain the hyperimage of any significance it might have in opening the spectacular images of the end times to ideological contestation. These 
images must simply be consumed as one might consume a movie we see for entertainment. In this instance, monologic images are merged with popular heteroglossic symbols so that the creativity encapsulated in symbolic acts are personified in anonymous monologic meanings, voices and images. “"The voice of life itself”, “the voice of nature”, “the voice of the people”, “the voice of God”...' (Bakhtin 1986, 163) are illustrations presented by Bakhtin of typical anonymous monological meanings, voices and images that seek to sweep up creative heteroglossic symbols to make the latter anonymous too. To return to a point we made earlier, in the modern world the most visible monologic force of unity is represented most typically through state power; a power where hegemonic forces will seek to penetrate heteroglossic culture and speak for it by 'fusing "the language of (monologic) truth" with "the language of the everyday"' (Bakhtin 1981, 315). The next section therefore starts to explore these issues in more depth.

\section{The material state of myths}

The increasing intrusion of the camera - the perennial third wheel - is illustrated by the publication of controversial pictures of Muammar Gaddafi taken as he was dying. At the time, Guardian writer Mark Lawson (2011) commented that,

... the pictures of the terrified, wounded and then possibly dead Muammar Gaddafi used on TV bulletins and the print and online editions of newspapers in the last 24 hours seemed to me to be, by some distance, the most graphic and distressing representations we have ever seen of a recognisable individual during his final moments...The most significant (and probably irresistible) 
change...is that the dissemination of contentious images has now largely left the desks of editors and regulators. Symbolically and crucially, the footage of Gaddafi's capture and assault was shot not by a crew but by a crowd on cellphones. TV or newspaper editors who ethically decide to bin the most distressing images know, unlike their predecessors, that the views will be generally available elsewhere and that curiosity will draw a large part of the audience there.

Hyperimages of individuals facing their own immanent mortality without hope of rescue make the coldly statistical theme of world apocalypse small and personal enough for viewers to enter the thresholds of the lives of others. Not only Gaddafi but also beheadings, the people falling to their death from the World Trade Center, the man kneeling in the sand his back to the oncoming 2004 Boxing Day Tsunami he knows to be inescapable.

In one important respect, these apocalyptic hyperimages create myths that naturalise certain ideological relations. For instance, the politicisation of these images by the right is achieved through fear; if we do not want to die the way our favourite non-fictional characters do - the ones with the huge number of YouTube views - we must allow our regimes more power, more force in our name. The more common the terror, obsession, death wish or lurid display of genuinely threatening global warming, economic collapse or authoritarian violence that the hyperimage evokes, the more vivid, intense and unforgettable the hyperimage is the more it is deprived of intelligibility. Crises and catastrophes, imperialist warfare and fundamentalist violence are thus potentially rendered dead by apocalyptic images and spectacles.

However, to retrieve a more critical perspective on these mythical images would require an alternative starting point to the one outlined by theorists such as 
Baudrillard. For example, Baudrillard simply sees the political system as a hyperreal one mediated through the likes of opinion polls that simulate political questions and answers rather than open up a space for real antagonisms to flourish (Baudrillard 1993, 67). As we have already indicated, an alternative critical perspective should seek to test the limits of hyperimages by teasing out the inherent inner dialectical quality of images, to show that they are refractions of symbolic and material social relations built on factors such as power, ideology, crisis and contradictions (Voloshinov 1973, 13). In terms of the apocalypse, rather than withdraw into the hyperreal, the task is to subject hyperimages to the heteroglossia of live intelligibility, to approach such images dialectically as symbolic refractions of material life. In this way, it becomes possible to challenge the hegemonic and visible expression of a dominant monologic hyperimage, one, in other words, domesticated when mistaken, perhaps even wilfully, for being just another instance of the hyperreal.

Hobsbawm (2011, 324-327) writes that, 'the basic problem of the revolution is how to make a hitherto subaltern class capable of hegemony, believe in itself as a potential ruling class and be credible as such to other classes... the struggle to turn the working class into a potential ruling class, the struggle for hegemony, must be waged before the transition of power, as well as during and after it'. The principal site of this ideological contestation is of course the state. As Gramsci observes:

If political science means science of the State, and the State is the entire complex of practical activities with which the ruling class not only justifies and maintains its dominance, but manages to win the active consent of those over whom it rules, then it is obvious that all the essential questions of sociology are nothing other than the questions of political science (Gramsci 2003 [1929-1935], 244). 
Unlike postmodern thinkers, for example Baudrillard, who tend to argue that it is a modernist error to think that a 'real' struggle still occurs over how a central force like the state regulates images in society, we think, in terms similar to Gramsci, it is crucial to hold onto a theory of the state when critically examining images and myths of the apocalypse. When one thinks about how wars are staged in the world today, it seems hardly a coincidence that an apocalyptical narrative is constructed by powerful states about, say, global terrorism, at the moment these very same governments move their military might into 'failed states' like Iraq to implement neoliberal agendas (Roberts 2010). In the words of James Davis:

In part, for the mainstream right, immigrant scapegoating, along with attacks on multiculturalism and on the economic position of the working class, is an electoral strategy that puts the left and social democratic opposition of the defensive. In periods of economic decline and insecurity, fear generated around these cultural and social issues helps to obscure coherent critiques of economic life. Reproduced as state catastrophism they help to reinforce this fragmentation of the left' (Davis 2012, 101).

As Davis indicates, and as Marxists like Gramsci, along with critical thinkers like Foucault, make explicit, the state is not simply cut-off from the rest of society but establishes mechanisms of governance and 'organic intellectuals' in society in order to articulate a hegemonic project through everyday 'cultural and social issues’.

State and society therefore have a dialectical relationship with one another. Nicos Poulantzas is worth quoting at length on this fundamental point.

Now, (a) We know that political strategy must be grounded on the autonomy of the organisations of the popular masses. But the attainment of such 
autonomy does not involve the political organisations in leaving the strategic field of the relationship of forces that is the power-State, any more than it involves other organisations such as the trade unions in taking up a position outside the corresponding power mechanisms. To believe that this is even possible is an old illusion of anarchism (in the best sense of the term). Moreover, in neither case does self-organisation on the terrain of power imply that these organisations must directly insert themselves in the physical space of the respective institutions (this will depend on the conjuncture), nor $a$ fortiori that they must embrace the materiality of these institutions (quite the contrary). (b) We also know that, alongside their possible presence in the physical space of the state apparatuses, the popular masses must constantly maintain and deploy centres and networks at a distance from these apparatuses: I am referring, of course, to movements for direct, rank-and-file democracy and to self-management networks. But although these take up political objectives, they are not located outside the State or, in any case, outside power - contrary to the illusions of anti-institutional purity. What is more, to place oneself at any cost outside the State in the thought that one is thereby situated outside power (which is impossible) can often be the best means of leaving the field open for statism: in short, it often involves a retreat in the face of the enemy precisely on this strategically crucial terrain (Poulantzas 2000 [1978], 153).

Struggles to construct monologic hyperimages of the apocalypse must not therefore ignore, in our information age, the power of the state to control, govern, and regulate these hyperimages through hegemonic political projects (see also Roberts 
2014). Genuine alternatives to what the aforementioned images present can thus also be fleshed out through such struggles. For Bakhtin and his colleagues, it is indeed vital that we take account of both dispersed heteroglossic accents and centralised monologic modes of regulation, such as hegemonic state projects. By recognising this relatively simple but important point, one becomes better equipped to challenge monologic myths and to dialogise them through progressive heteroglossic voices based in the contradictions of real material life. Indeed, the distance between mediacorrespondent and media-observer is closing, the interval between perception and interpretation shortened to the point of being indiscernible and thus denotive. Discerned in the temporal and spatial voids that do still persist between the two are the faint echoes of class and social struggles and the possibility to amplify and concretise them through the clash of live accents on the streets, in the squares and in workplaces. They present the possibility to make abstract processes and relations of a standardised apocalypse intelligible and subject to the clash of live accents.

\section{Conclusion}

One political danger is that the current slide towards authoritarianism in liberal democratic societies, especially the empowering of law and order to combat the perceived catastrophe of 'global terrorism', the seeming incapacity of the state to tame finance or corporate power, or the left to seize the reins of power, brings to the fore a sense of apocalyptic fatalism. Hardt and Negri warn of a leftist thinking which portrays the villain as an overwhelming political power, either sovereign or fascist, so that it seems 'there are no forces of liberation inherent in such a power that, though 
now frustrated and blocked, could be set free. There is no hope of transforming such a power on a democratic course. It needs to be opposed, destroyed, and that is all' (Hardt and Negri 2009, 5). A void opens up to be populated by new apocalyptic myths. In this respect, capitalist crises spiral towards a point of abjection, desertification, radiated soils, dead zones from which nothing, not even fantasies, can emerge.

The left today thus threatens to be consumed by its own belief in its capacity to change the world by bypassing the state, a position exemplified by global social movements, and exemplified, as we have argued, by certain postmodern strands of thought (cf. Cremin and Roberts 2011). There is, however, no autonomous space that has not already been commodified or subject to the law of surplus value, no individual that can persist except by its logic, and the state is required to develop this logic further in civil society through its regulation of money and law (Clarke 1988). Given the materially embedded nature of the capitalist state - that, as Poulantzas points out, condenses the broader social relations and ideologies that emanate from different spheres of influence and essentially the class struggle itself - it is thus a crucial terrain of contestation. As Leo Panitch (2014), writing in the Guardian, says,

The left used to beat itself up, sometimes quite literally, with debates over reform vs revolution, parliamentarianism vs extra-parliamentarianism, party vs movement - as if one ruled out the other. The question for the 21st century is not reform $\mathrm{v}$ revolution, but rather what kinds of reforms, with what kinds of popular movements behind them engaging in the kinds of mobilisations that can inspire similar developments elsewhere, can prove revolutionary enough to withstand the pressures of capitalism. 
We would add that where apocalypses are generally revelatory and redemptive, capitalist apocalypses are contingent, the truths they expose are unlikely to lead to a world beyond capitalism. Revolutions differ in this respect. They are brought about by collective and self-conscious activity, not by some divine intervention. As Silver and Arrighi (2011) explain,

... a long and deep period of systemic chaos - analogous but not identical to the systemic chaos of the first half of the twentieth century - remains a serious historical possibility. While the end of the long twentieth century is inevitable, there is nothing inevitable about it coming to a catastrophic ending. Avoiding the latter is our urgent collective task (Silver and Arrighi 2011, 68).

This is not to deny that the decade of the '00s was punctuated with political crises and images of human-engendered disaster in prosperous, developed countries: 9/11, the aftermath of Hurricane Katrina and the global financial crisis. The hyperimage functions as the condensation of the processes and events denoting an apocalyptic age in visual forms depicting and forewarning calamities that almost inevitably will consume or kill us if nothing is done about it. Almost inevitably: it's in this narrow gap that the struggle for meaning occurs and where control of the meaning of hyperimages is of vital importance to the future of society.

As we have argued, language for the Bakhtin Circle is rendered dead or monoglossic when refracted through the prism of a dominant ideology, but rendered alive when subjected to the heteroglossia of competing 'accents'. '(A)t any given moment of its historical existence,' Bakhtin explains,

language is heteroglot from top to bottom: it represents the co-existence of socio-ideological contradictions between the present and the past, between different epochs of the past, between different socio-ideological groups in the 
present, between tendencies, schools, circles and so forth, all given a bodily form. These "languages" of heteroglossia intersect each other in a variety of ways, forming new socially typifying “languages” (Bakhtin 1981, 291).

The question for this paper has been whether the widely documented events, processes and relations, refracted in the phantasmagoria of media spectacle, that together denote an apocalyptic age, are the subject of live heterglossic intelligibility, or whether - through the monoglossia of the single accent which typically posits that there is no prospect to change the course of history - they have rendered the future already dead. Put another way, in the midst of capitalist abstraction concretised by economic crises and symptoms of anthropogenic ${ }^{2}$ climatic change that echoes in every utterance, the political task is to bring the language of end times to life. The clash of live accents negates the monoglossia of economic liberalism alongside cynicism, resignation and fantasies of total collapse, to realise the possibility of a different future to that forewarned of by scientists, prescribed by economists, accommodated by politicians and made spectacle by the entertainment industry. What does this concretely entail? Competing accents on social media risk in an age of information overload becoming as Virilio said of the 'information bomb' mere fallout. Our conclusion is that the struggle for control of the image, an image that negates the cynicism of our 'apocalyptic' age, must necessarily occur on the terrain of the state. Moreover, and unlike our 'post'-theorists, we still hold faith that Marxist theory can help us critically analyse myths of the apocalypse. As Fredric Jameson puts it:

\footnotetext{
2 This is a mystifying term given that it is not human life per se that has brought us to the brink of cataclysmic climate change but rather capitalist mode of production, distribution, exchange and consumption. A preferable term, albeit and inelegant one, to denote this 'geological' age is the Capitocene (Cremin 2015).
} 
The point is that Marx alone sought to combine a politics of revolt with the 'poetry of the future' and applied himself to demonstrate that socialism was more modern than capitalism and more productive. To recover that futurism and that excitement is surely the fundamental task of any left 'discursive struggle’ today (Jameson 2012, 90).

\section{References}

Adorno, Theodor and Horkheimer, Max 1997. Dialectic of Enlightenment. London: Verso.

Bakhtin, Mikhail 1981. The Dialogic Imagination, trans. C. Emerson and M. Holquist. Austin, Texas: University of Texas Press.

Bakhtin, M. 1984. Rabelais and His World, trans. H. Iswolsky. Bloomington, Indiana: University of Indiana Press.

Bakhtin, M. 1984. The Problems of Dostoyevsky's Poetics, trans. C. Emerson. Minnesota: University of Minnesota Press.

Bakhtin, M. 1987. Speech Genres and Other Late Essays, trans. V. W. McGeee. Austin: University of Texas Press.

Bakhtin, M. Medvedev, P. 1991. The Formal Method in Literary Scholarship: A Critical Introduction to Sociological Poetics. London: The Johns Hopkins Press.

Barthes, R. 2009. Mythologies, trans. A. Lavers. London: Vintage.

Baudrillard, J. 1993. Symbolic Exchange and Death, trans I. H. Grant. London: Sage. 
Baudrillard, J. 2010. Carnival and Cannibal or the Play of Global Antagonism. London: Seagull Books.

Baudrillard, J. 2003. The Spirit of Terrorism. London: Verso.

Bosteels, B. 2011. The Actuality of Communism. London: Verso.

Borger, J. 2014. “Ban Ki-moon: 'World Living in an Era of Unprecedented Level of Crises'”. The Guardian. http://www.theguardian.com/world/2014/sep/21/banki-moon-world-living-era-undprecedented-level-crises

Boyer, P. 1992. When Time Shall Be No More. Massachusetts: Harvard University Press.

Buck-Morss, S. 2002. Dreamworld and Catastrophe: The Passing of Mass Utopia in East and West. Cambridge MA: The MIT Press.

Clarke, S. 1988. Keynesianism, Monetarism and the Crisis of the State. Aldershot and Gower, Vermont. Edward Elgar.

Cremin, C. 2015. Totalled: Salvaging the Future from the Wreckage of Capitalism. London: Pluto Press.

Cremin, C. and Roberts, J.M. 2011. "Postmodern Left-Liberalism: Hardt and Negri and

the Disavowal of Critique.” Critical Sociology 32(2): 179-197

Davis, J. 2012. “At War with the Future: Catastrophism and the Right”. In Catastrophism: The Apocalyptic Politics of Collapse and Rebirth, edited by S. Lilley, D. McNally, E. Yuen, and J. Davis, 77-107. Oakland, CA: PM Press.

Deleuze, G. 1986. Cinema 1. London: Continuum.

Derrida, J. 1984. “No Apocalypse, Not Now (Full Speed Ahead, Seven Missiles, Seven Missives)” Diacritics 14(2): 20-31.

Dixon, W. 2003. Visions of the Apocalypse: Spectacles of Destruction in American 
Cinema. London: Wallflower Press.

George, S. 2010. Whose Crisis, Whose Future? Cambridge: Polity Press.

Gramsci, A. 2003. Selections from the Prison Notebooks. London:

Lawrence and Wishart.

Hardt, M. Negri, A. 2009. Commonwealth. Cambridge: Harvard University Press.

Harvey, D. 2014. Seventeen Contradictions and the End of Capitalism. London: Profile Books.

Hobsbawm, E. 2011. How to Change the World. London: Little Brown.

Hobsbawm, E. 1983. “Introduction: Inventing Tradition”. In The Invention of

Tradition edited by E. Hobsbawm and T. Ranger, pp 1-14. Cambridge: Cambridge University Press.

Jameson, F 2012. Representing Capital: A Reading of Volume One. London: Verso.

Jensen, D. 2006. Endgame Vol. 1: The Problem of Civilization. New York : Seven Stories Press.

Lawson, M. 2011. "Even Muammar Gaddafi Deserved a Private Death". The Guardian

http://www.theguardian.com/commentisfree/2011/oct/21/muammar-gaddafideath-images-media.

Lilley, S. 2012. “The Apocalyptic Politics of Collapse and Rebirth” In Catastrophism: The Apocalyptic Politics of Collapse and Rebirth, edited by S. Lilley, D. McNally, E. Yuen, and J. Davis, 1-14. Oakland, CA: PM Press.

Marx, K. 2001. Capital: Volume 1. London: Penguin.

Milne, E., Mitchell, C. and de Lange, N. 2012. Handbook of Participatory Video. Plymouth: Altamira Press. 
Mosco, V. 2004. The Digital Sublime. Cambridge, MA: The MIT Press.

NatCen Social Research. 2013. “Public Attitudes to Poverty and Welfare 1983-2011”. http://www.natcen.ac.uk/our-research/research/public-attitudes-to-povertyand-welfare-1983-2011.

Noys, B. 2012. The Persistence of the Negative: A Critique of Contemporary Continental Theory. Edinburgh University Press.

Panitch, L. 2014. “Europe’s Left has Seen How Capitalism can Bite Back”. The

Guardian. http://www.theguardian.com/commentisfree/2014/jan/12/europeleft-capitalism-social-democrats-reforms.

Portelli, A. (1990) “Unchronic Dreams: Working Memory and Possible Worlds”. In The Myths We Live By, edited by P. Thompson and R. Samuel (eds), 143-160. London: Routledge.

Poulantzas, N. 2000. State, Power, Socialism, second edition. London: Verso.

Ramesh, R. (2013) “Labour Voters Increasingly Turning against the Poor, Study Says'.

The Guardian. http://www.theguardian.com/politics/2013/may/14/labourvoters-poor-study-solidarity.

Roberts, J. 2010. “The State, Empire and Imperialism”. Current Sociology 58(6): 833858.

Roberts, J.M. 2014. Digital Publics. London: Routledge.

Samuel, R. and Thompson, P. 1990. “Introduction” In The Myths We Live By, edited by P. Thompson and R. Samuel, 1-22. London: Routledge.

Silver, B. and Arrighi, G. 2011. "The Long Twentieth Century”. In Business as Usual: 
The Roots of the Global Financial Meltdown, edited by G. Calhoun and G. Derluguian, 53-68. New York: New York University Press.

Virilio, P. 200.) The Information Bomb. London: Verso.

Voloshinov, V. N. 1973. Marxism and the Philosophy of Language, trans. L.

Matejka and I. R. Titunik. New York: Seminar Press.

Williams, E.C. 2011. Combined and Uneven Apocalypse. Hants: Zer0 Books.

Žižek, S. 2002. Welcome to the Desert of the Real. London: Verso.

Žižek, S. 2010. Living in the End Times. London: Verso. 